\title{
Efisiensi teknis usahatani padi sawah pasang surut varietas lokal di Kecamatan Barambai Kabupaten Barito Kuala: pendekatan Dea
}

\author{
Hatimatul Husna*, Yusuf Azis, Muhammad Fauzi \\ ${ }^{1}$ Program Studi Agribisnis, Fakultas Pertanian, Universitas Lambung Mangkurat, Banjarbaru, Indonesia \\ *E-mail: husna.atul95@gmail.com
}

\begin{abstract}
The province of South Kalimantan has a large area of tidal land. Most of it is in Barito Kuala Regency. The utilization of tidal land has considerable potential in developing agriculture, especially for rice. The purpose of this study was to analyze the technical efficiency of tidal lowland rice farmers in Barambai District using the Data Envelopment Analysis (DEA) approach, to analyze the effect of respondent characteristics on technical efficiency in Barambai District using Tobit Regression, to analyze the profits of tidal lowland rice farmers in the District Barambai. This research was conducted in three villages in Barambai District, Barito Kuala Regency, which were determined purposively by selecting 60 sample farmers. Based on the study results, there were four efficient farmers with an average efficiency level of 0.893 . Of the four characteristics of sample farmers, three characteristics affect technical efficiency; namely, age has a negative effect, length of formal education, and the number of dependents of household members positively affect. Meanwhile, the length of experience in farming does not affect. Revenue from farmers is IDR 13,609,917/farm or IDR $15,869,420 /$ hectare. While the income earned is Rp. 11,411,300/farm or Rp. 13,305,792/hectare, so that the profit is Rp. 7,172,502/farm or Rp. 8,363,262/hectare.
\end{abstract}

Keywords: efficiency, Data Envelopment Analysis, Tobit Regression

Abstrak. Provinsi Kalimantan Selatan memiliki lahan pasang surut cukup luas dan sebagian besarnya di Kabupaten Barito Kuala.Pemanfaatan lahan pasang surut berpotensi cukup besar dalam mengembangkan pertanian terutama untuk padi. Tujuan penelitian ini adalah untuk menganalisis efisiensi teknis petani padi sawah pasang surut di Kecamatan Barambai menggunakan pendekatan Data Envelopment Analysis (DEA), untuk menganalisis pengaruh karakteristik responden terhadap efisiensi teknis di Kecamatan Barambai menggunakan Tobit Regression, untuk menganalisis keuntungan petani padi sawah pasang surut di Kecamatan Barambai. Penelitian ini dilakukan di tiga desa di Kecamatan Barambai Kabupaten Barito Kuala yang ditentukan secara purposive dengan memilih 60 petani sampel. Berdasarkan hasil penelitian terdapat 4 petani yang efisien dengan nilai rata-rata tingkat efisiensi 0,893 . Dari 4 karakteristik petani sampel, ada 3 karakteristik yang berpengaruh terhadap efisiensi teknis yaitu usia berpengaruh negatif, lama pendidikan formal dan jumlah tanggungan anggota rumah tangga berpengaruh positif. Sedangkan untuk lama pengalaman berusahatani tidak berpengaruh. Penerimaan petani adalah Rp 13.609.917/usahatani atau Rp 15.869.420/hektar. Sedangkan pendapatan yang diperoleh Rp 11.411.300/usahatani atau Rp 13.305.792/hektar sehingga keuntungan Rp 7.172.502/usahatani atau Rp 8.363.262/hektar.

Kata Kunci: efisiensi teknis, Data Envelopment Analysis, model Tobit Regression

\section{PENDAHULUAN}

Negara Indonesia merupakan negara yang memiliki jumlah penduduk cukup banyak. Jumlah penduduk di Indonesia terus meningkat.Jumlah penduduk meningkat mengakibatkan meningkatnya jumlah permintaan terhadap tanaman pangan, termasuk padi. Selain itu sebagian besar penduduk di Indonesia bermata pencaharian sebagai petani. Oleh karena itu sektor pertanian memiliki peranan 
penting dalam perekonomian nasional. Salah satu provinsi di Negara Indonesia adalah Kalimantan Selatan. Sebagian besar penduduk di Kalimatan Selatan bermata pencaharian sebagai petani.

Kabupaten Barito Kuala merupakan salah satu kabupaten yang ada di Provinsi Kalimantan Selatan. Kabupaten Barito Kuala adalah kabupaten yang memiliki luas panen terbesar di Provinsi Kalimantan Selatan Dari tahun 2014 hingga tahun 2016 (BPS Kalimantan Selatan,2017). Kecamatan Barambai merupakan salah satu kecamatan di Kabupaten Barito Kuala yang menjadi sentra penghasil padi sawah. Dalam proses produksi, untuk memperoleh produksi maksimal, maka petani harus menggunakan faktor produksi secara tepat dan efisien.

Usahatani merupakan suatu bentuk kombinasi penggunaan faktor produksi yang diusahakan oleh seseorang atau suatu organisasi untuk mendapatkan atau memperoleh suatu produk pertanian (Soekartawi, 1986: 112). Salah satu alat yang bisa digunakan dalam suatu analisis usahatani adalah dengan pendekatan Data Envelopment Analysis (DEA) yaitu suatu alat analisis yang bisa memberikan rujukan untukjumlah digunakannya faktor produksi yang seharusnya dipergunakan dalam suatu usahatani (Soekartawi, 1995: 98). Efisiensi adalah suatu kemampuan usaha untuk menghasilkan keluaran tertentu dengan mempergunakan sejumlah faktor produksi tertentu dengan optimal (Dumaria, 2003: 79).

Salah satu dari beberapa metode frontier non-parametric yaitu pendekatan DEA yang digunakan untuk mengukur efisiensi kinerja dengan menggunakan banyak faktor produksi dan output pada suatu usaha yang memiliki faktor produksi dan keluaran yang sama dengan pembobotan pada variabel yang digunakan. DEA digunakan untuk mengukur efisiensi relatif dari setiap responden (Sudaryanto,2006: 87).

Untuk keperluan perhitungan pendapatan usahatani, biaya usahatani dapat dikelompokan menjadi dua kelompok yaitu biaya eksplisit dan biaya implisit. Biaya eksplisit adalah semua biaya yang secara nyata dikeluarkan oleh petani dalam penyelenggaraan usahatani. Biaya implisit adalah biaya yang sifatnya hanya diperhitungkan saja sebagai biaya, meskipun tidak benar-benar merupakan pengeluaran yang dibayarkan secara nyata oleh petani.

Tujuan dari pelaksanaan penelitian ini adalah: (1) Menganalisis efisiensi teknis petani padi sawah pasang surut di Kecamatan Barambai berdasarkan tahun 2018 menggunakan pendekatan Data Envelopment Analysis; (2) Menganalisis pengaruh karakteristik responden terhadap efisiensi teknis di Kecamatan Barambai; (3) Menganalisis keuntungan petani padi sawah pasang surut di Kecamatan Barambai tahun 2018.

Kegunaan dari pelaksanaan penelitian ini adalah: (1) Pemerintah, dapat menjadi bahan pertimbangan bagi para pengambil kebijakan dalam menentukan kebijakan pengembangan padi sawah pasang surut sehingga produksi padi nasional dapat memenuhi kebutuhan dalam negeri tanpa menekan produsen; (2) Petani, diharapkan dengan adanya penelitian ini dapat mengubah cara pandang petani mengenai pentingnya keuntungan yang diperoleh dalam suatu usahatani.

\section{METODE}

\subsection{Lokasi dan Waktu Penelitian}

Variabel yang digunakan dalam penelitian ini adalah 1) jumlah produksi kopi arabika, satuan kilogram (kg); 2) jumlah pupuk, satuan kilogram (Kg); 3) jumlah bibit, satuan (pohon); 4) jumlah tenaga kerja, satuan Hari Kerja Pria (HKP); 5) luas lahan, satuan are; 6) umur adalah satuan tahun; 7) tanggungan keluarga, satuan orang; 8) pengalaman usahatani, satuan tahun, 9) tingkat pendidikan formal, satuan tahun.

\subsection{Jenis dan Sumber Data}

Jenis dan sumber data yang digunakan dalam penelitian ini adalah data primer dan sekunder. Data primer diperoleh dengan cara melakukan wawancara kepada petani sampel dengan menggunakan daftar pertanyaan yang telah disiapkan sebelumnya. Sedangkan data sekunder diperoleh dari dinas ataupun kementerian terkait sebagai sumber untuk menentukan lokasi penelitian, serta literaturliteratur yang juga berhubungan dengan penelitian ini.

\subsection{Metode Penentuan Responden}

Penentuan sampel desa penelitian dilakukan secara purposive, yaitu diambil 3 desa di Kecamatan Barambai yang menjadi sentra produksi padi sawah. Sampel desa yang terpilih adalah Desa Bagagap, 
Desa Barambai Kolam Kiri Dalam dan Desa Karya Tani., Selanjutnya petani responden di tiap desa diambil dengan metode proportioned random sampling, yaitu menggunakan rumus $n_{i}=\frac{n k}{N} x$, sehingga diperoleh 15 petani sampel di Desa Bagagap, 16 petani sampel di Desa Barambai Kolam Kiri Dalam, dan 29 petani sampel di Desa Karya Tani, maka didapat 60 responden petani sampel

\subsection{Analisis Data}

Data primer yang digunakan dianalisis secara kuantitatif dengan menggunakan $D E A$ untuk mengukur efisiensi teknis relatif dari berbagai usahatani yang dijadikan sebagai petani sampel. Data yang terkumpul dari petani sampel diolah menggunakan software DEAP 2.1. Keluaran dari software tersebut memperlihatkan bahwa tingkat efisiensi relatif dari setiap petani sampel terhadap petani sampel lain dalam usahatani yang diteliti. Microsoft Excel 2010 digunakan untuk mengolah data pada analisis keuntungan, biaya, penerimaan maupun pendapatan. STATA 11 untuk menganalisis pengaruh antara karakteristik responden dengan nilai efisiensi teknis menggunakan pengujian Tobit Regression.

Untuk menjawab tujuan pertama, yaitu untuk menganalisis efisiensi teknispada usahatani padi sawah pasang surut dengan menggunakan pendekatan DEA. Pendekatan ini dipergunakan sebab sederhana dan tidak memerlukan banyak variabel. Asumsi constant return to scale dan input oriented dipergunakan sebab penelitian ini hanya dilakukan pada satu periode waktu. Nilai efisiensi teknis berdasarkan CRS adalah sebesar 1,00 (100\%).

Untuk menjawab tujuan kedua, yaitu menganalisis pengaruh karakteristik petani padi sawah terhadap efisiensi teknis. Pertama yang dilakukan adalah pengujian pengaruh dan signifikansi pengaruh antara dua variabel yang dibandingkan. Pengujian tersebut dilakukan dengan bantuan alat analisis STATA 11. Pendekatan yang digunakan adalah menggunakan pengujian Tobit Regression. Penggunaan model Tobit ini berdasarkan pertimbangan bahwa variabel dependen dalam penelitian ini adalah tingkat efisiensi teknis yang memiliki batas nilai antara 0 sampai dengan 1 atau consuret variable. Model estimasi faktor yang berpengaruh terhadap tingkat efisiensi menggunakan model Tobit yang disajikan sebagai berikut :

$$
\begin{aligned}
& \mathrm{TE}=\beta_{0}+\beta_{1} \mathrm{UP}+\beta_{2} \mathrm{PF}+\beta_{3} \mathrm{AT}+\beta_{4} \mathrm{LU}+\varepsilon(1) \\
& \text { dengan:TE } \text { tingkat efisiensi teknis } \\
& \mathrm{UP} \text { usia petani (tahun) } \\
& \mathrm{PF} \text { pendidikan formal (tahun) } \\
& \mathrm{AT} \text { Jumlah anggota rumah tangga (orang) } \\
& \mathrm{LU} \text { lama berusahatani padi (tahun) }
\end{aligned}
$$

Untuk menjawab tujuan ketiga, yaitu menganalisis pendapatan petani padi sawah pasang surut dengan menggunakan Microsoft Excel 2010. Penerimaan adalah nilai dari hasil panen yang sudah melalui tahap pasca panen dan siap digiling dikalikan dengan nilai jual per unit.

Nilai harga beli diperoleh dari harga saat responden membeli peralatan yang dipergunakan dalam usahatani tersebut. Nilai sisa diperoleh dariterdapat atau tidaknya peralatan tersebut kemungkinan untuk dijual, apabila sudah tidak dipergunakan lagi. Umur ekonomis diperoleh dari lama menggunakan peralatan tersebut hingga akhirnya memutuskan membeli peralatan baru. Berikut rumus untuk menghitung biaya penyusutan:

Penyusutan $=\frac{\text { Harga Pembelian }- \text { Nilai Sisa }}{\text { Umur Ekonomis }}(2)$

Biaya eksplisit usahatani merupakan biaya yang secara nyata dikeluarkan oleh petani dalam pelaksanaan usahataninya, mulai dari persiapan usahatani hingga pasca panen. Biaya implisit usahatani merupakan biaya yang dikeluarkan secara tidak langsung oleh petani itu sendiri dalam proses usahatani. Biaya total diperoleh dari biaya eksplisit dijumlah dengan biaya implisit.Adapun rumus untuk mendapatkan biaya total usahatani padi, yaitu: 
$\mathrm{TC}=\mathrm{TCe}+\mathrm{TCi}(3)$

dengan: TC biaya total usahatani padi (Rp)

TCe biaya eksplisit usahatani padi (Rp)

$\mathrm{TCi}$ biaya implisit usahatani padi (Rp)

Penerimaan total usahatani adalah hasil perkalian antara banyaknya jumlah output yang diperoleh selama masa produksinya dari suatu usahatani dengan harga dari hasil produksinya. Adapun rumus untuk mendapatkan penerimaan total usahatani padi, yaitu:

$\mathrm{TR}=\mathrm{Y} \cdot \mathrm{Py}$

dengan:TR penerimaan total usahatani padi $(\mathrm{Rp})$

Y banyaknya output yang diperoleh selama masa produksinya (1 blek=20 liter)

Py harga dari hasil produksi cabang usahatani padi (Rp/blek)

Pendapatan usahatani adalah penerimaan dikurangi dengan biaya total eksplisit. Adapun rumus untuk mendapatkan pendapatan usahatani padi, yaitu:

$\mathrm{FI}=\mathrm{TR}-\mathrm{TCe}$

dengan:FI pendapatan usahatani padi (farmingIncome)

TR penerimaan total usahatani padi(Rp)

TCe biaya eksplisit usahatani padi (Rp)

Keuntungan usahatani adalah pengurangan antara penerimaan usahatani dengan total biaya (biaya eksplisit ditambah dengan biaya implisit). Adapun rumus untuk mendapatkan keuntungan usahatani padi, yaitu:

$\pi=\mathrm{TR}-\mathrm{TC}$

dengan:л

keuntungan usahatani padi (Rp)

TR penerimaan total usahatani padi (Rp)

TC biaya usahatani padi $(\mathrm{Rp})$

\section{HASIL DAN PEMBAHASAN}

\subsection{Efisiensi Teknis dengan Pendekatan DEA}

Nilai efisiensi teknis pada penelitian ini menggunakan DEA CRS (Constant Return to Scale) untuk menentukan kecenderungan trend petani padi. Dengan asumsi, petani padi beroperasi pada skala yang optimal maka menggunakan model CRS dan petani yang telah mencapai efisien secara teknis sebanyak 4 orang petani sampel, yaitu petani ke 6,9,11, dan 37. Nilai efisiensi teknis berdasarkan CRS adalah sebesar 1,00 (100\%). Nilai rata-rata efisiensi teknis petani padi pada penelitian ini adalah 0,893 , nilai efisiensi teknis terendah 0,727 dan tertinggi adalah 1,000 .

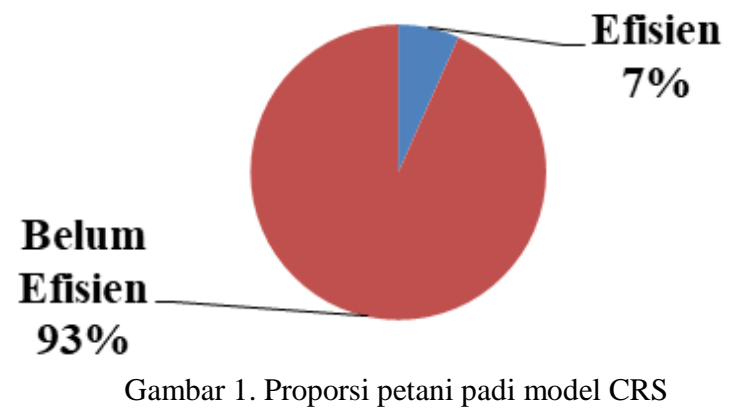


Menggunakan DEA dapat diketahui perbandingan antara petani yang diteliti. Petani yang telah mencapai efisien menjadi rujukan bagi petani yang belum efisien dengan melakukan perbandingan penggunaan faktor produksinya.

Empat orang yang efisien secara teknis tersebut menjadi peer. Perbandingan antar petani dapat dilihat pada sebaran peer hasil analisis DEA. Sebagai contohya, dapat dilihat perbandingan antara petani 1 dengan 3 petani lainnya yaitu petani 9, 11, dan 37. Untuk mendapatkan nilai output yang sama, petani 1 menggunakan alokasi input yang berlebih, dimana luas tanam berlebih sebanyak 0,245 ha, penggunaan benih berlebih sebanyak 2, $401 \mathrm{~kg}$, penggunaan pupuk berlebih sebanyak $176,435 \mathrm{~kg}$, pestisida kelebihan penggunaan sebesar 1,347 liter, pengunaan tenaga kerja manusia berlebih sebanyak 17,994 HOK serta pengunaan tenaga kerja mesin berlebih sebanyak 1,517 JKM. Berikut secara ringkas hasil analisis efisiensi untuk petani padi 1 pada Tabel 1.

\begin{tabular}{cccc}
\multicolumn{4}{c}{ Tabel 1. Hasil analisis efisiensi untuk petani padi 1 } \\
\hline Variabel & Nilai awal & Slack & $\begin{array}{c}\text { Nilai efisiensi } \\
\text { berdasar petani 9, } \\
11 \text { dan 37 }\end{array}$ \\
\hline Produksi (Y) & $2.350,000$ & 0,000 & $2.350,000$ \\
Luas lahan (X1) & 1,090 & $-0,245$ & 0,845 \\
Benih (X2) & 8,250 & $-2,401$ & 5,849 \\
Pupuk (X3) & 415,000 & $-176,435$ & 238,565 \\
Pestisida (X4) & 6,000 & $-1,347$ & 4,653 \\
TK manusia (X5) & 80,130 & $-17,994$ & 62,136 \\
\hline
\end{tabular}

Sumber: Pengolahan data primer (2019)

Jika dilihat dari perspektif peer nya, beberapa petani menjadi peer terhadap petani lain dengan frekuensi yang berbeda. petani yang memiliki frekuensi tertinggi menjadi peer terhadap petani yang lain adalah petani 9 dan 37 dengan frekuensi sebanyak 56 kali, begitu juga petani 11 dengan frekuensi sebanyak 51 kali, kecuali untuk petani ke 60 kali. Input slack menunjukkan faktor produksi yang dapat dikurangi oleh petani akibat kelebihan penggunaan faktor produksi untukmenghasilkan tingkat output yang sama. Secara rinci nilai rata-rata input slack dari seluruh petani pada variabel input (faktor produksi) dapat dilihat pada Tabel 2 .

Tabel 2. Nilai input slack rata-rata petani padi

\begin{tabular}{cccc}
\hline Variabel & $\begin{array}{c}\text { Nilai slack rata- } \\
\text { rata }\end{array}$ & Satuan & $\begin{array}{c}\text { Frekuensi petani } \\
(\%)\end{array}$ \\
\hline Luas lahan & 0,002 & $\mathrm{Ha}$ & 10,00 \\
Benih & 0,444 & $\mathrm{Kg}$ & 92,00 \\
Pupuk & 73,892 & $\mathrm{Kg}$ & 93,00 \\
Pestisida & 0,265 & Liter & 37,00 \\
TK manusia & 0,172 & HOK & 8,00 \\
TK mesin & 0,278 & JKM & 57,00 \\
\hline Sumber: Pengolahan data primer (2019) & &
\end{tabular}

Penggunaan luas tanam memiliki rata-rata slack sebesar 0,002 ha. Petani yang masih mampu mengurangi penggunaan luas tanam rata-rata sebesar 0,002 ha dengan tanpa mengurangi hasil usahatani padinya yakni sebanyak 6 orang (10,00 persen). Pada kasus ini mengindikasikan bahwa ada petani yang berperilaku efisien (tingkat efisiensinya $=1,000$ ) yang menjadi peer bagi 12,00 persen petani untuk penggunaan input luas lahan padi. Pengurangan penggunaan luas tanam tersebut tidak akan mengurangi outputnya, seperti pada petani yang menjadi peer nya. Penggunaan input benih memiliki rata-rata slack sebesar $0,444 \mathrm{~kg}$. Petani yang masih mampu mengurangi penggunaan benih rata-rata sebesar $0,444 \mathrm{~kg}$ dengan tanpa mengurangi hasil usahatani padinya yakni sebanyak 55 orang (92,00 persen). Pada penggunaan pupuk, terdapat 56 (93,00 persen) petani yang berperilaku tidak efisien dengan rata-rata pupuk yang dapat dihemat sebesar 73,892 kg. Hal yang sama berlaku juga untuk penggunaan pestisida dimana rata-rata penggunaan pestisida yang dapat dihemat sebesar 0,265 liter dengan tanpa mengurangi hasil padi yang diperoleholeh 22 (37,00 persen) petani agar target produksinya sarna dengan petani peer nya. Tenaga kerja manusia memiliki nilai rata-rata slack sebesar 0,172 HOK. Ini menunjukkan bahwa pada 5 (8,00 persen) petani rnasih dapat dikurangi penggunaan, tenaga kerja manusianya rata-rata sebesar 0,172 HOK untuk mendapatkan output yang sama dengan 
petani yang menjadi peer-nya.Tenaga kerja mesin memiliki nilai rata-rata slack sebesar 0,278JKM. Ini menunjukkan bahwa pada 57\% petani rnasih dapat dikurangi penggunaan, tenaga kerja manusianya rata-rata sebesar $0,278 \mathrm{JKM}$ untuk mendapatkan output yang sama dengan petani yang menjadi peernya.

\subsection{Pengaruh Karakteristik Petani Petani Padi Sawah terhadap Efisiensi Teknik}

Usia. Usia dapat menentukan kondisi fisik dari seseorang dalam bekerja untuk memenuhi kebutuhan rumah tangga. Golongan usia antara 25-34 tahun merupakan kelompok usia yang paling banyak yaitu $31,67 \%$ petani. Usia petani sampel yang paling muda berada pada usia 25 tahun dan usia petani sampel yang paling tua berada pada usia 72 tahun, sedangkan untuk rata-rata usia petani sampel adalah 43 tahun.

Lama Pendidikan Formal. Pendidikan merupakan suatu proses agar seseorang dapat berubah menjadi lebih baik, mulai dari pengetahuan, keterampilan maupun sikap. Pendidikan dapat meningkatkan kualitas diri dari seseorang. Golongan tingkat pendidikan tidak tamat SD merupakan kelompok tingkat pendidikan yang paling banyak yaitu 46,67 \% petani. Tingkat pendidikan terendah adalah tidak sekolah (0 tahun), sedangkan tingkat pendidikan tertinggi adalah tidak tamat SMA (11 tahun). Rata-rata lama pendidikan formal petani sampel adalah 5 tahun.

Jumlah Tanggungan Anggota Rumah Tangga. Umumnya, semakin banyak anggota rumah tangga, maka semakin banyak pengeluaran. Akan tetapi juga, semakin banyak pula yang dapat berperan membantu dalam pekerjaan atau usaha, sehingga dapat menambah nilai pendapatan yang diperoleh rumah tangga tersebut. Golongan jumlah tanggungan anggota rumah tangga 2 orang merupakan kelompok yang memiliki jumlah tanggungan anggota rumah tangga yang paling banyak yaitu $45 \%$ petani. Jumlah tanggungan anggota rumah tangga yang paling sedikit adalah tidak memiliki tanggungan, sedangkan jumlah tanggungan anggota rumah tangga yang paling banyak adalah 6 orang. Rata-rata jumlah tanggungan anggota rumah tangga adalah 3 orang.

Lama Berusahatani Padi. Lama berusahatani berkaitan dengan pengalaman berusahatani. Pengalaman berusahatani padi yang banyak akan memberikan kontribusi yang positif terhadap kemampuan petani dalam mengatasi berbagai permasalahan berusahatani padi yang dihadapinya. Jumlah petani sampel yang paling banyak pada tingkatan pengalaman berusahatani padi sawah pada golongan antara 4-13 tahun, yaitu 30\% petani. pengalaman berusahatani padi yang paling rendah adalah 4 tahun, sedangkan pengalaman berusahatani padi yang paling lama adalah 49 tahun. Adapun rata-rata pengalaman berusahatani padi sawah selama 23 tahun.

Berdasarkan hasil penelitian ini dengan menggunakan analisis Tobit Regression, faktor yang mempengaruhi efisiensi teknis terdiri dari usia petani, lama pendidikan formal, dan jumlah tanggungan anggota rumah tangga dengan taraf kepercayaan $95 \%$ atau 0,05 . Sedangkan faktor yang tidak mempengaruhi efisiensi teknis adalah lama pengalaman berusahatani padi dengan taraf kepercayaan $95 \%$ atau 0,05 .

Jika dilihat dari usia, semakin tua seorang petani sampel maka tingkat efisiensinya semakin menurun, karena nilai koefisiennya yang bernilai negatif $(-0,0041539)$. Umumnya, semakin bertambahnya usia seseorang maka semakin menurun pula kemampuan seseorang tersebut dalam suatu kegiatan terutama untuk usahatani padi. petani yang berumur kurang dari 50 tahun akan menghasilkan usahatani yang lebih efisien dibandingkan petani yang berumur di atas 50 tahun. Kondisi di lapangan membuktikan bahwa petani yang berada pada usia tua dan hal ini ternyata dapat menurunkan efisiensi usaha taninya. Fenomena ini dapat dijelaskan bahwa semakin tua umur petani menyebabkan mereka semakin lemah dalam berusaha dan lamban atau kurang tertarik untuk menerima inovasi baru.

Jika dilihat dari lama pendidikan formal, semakin tinggi tingkat pendidikan seorang petani sampel maka tingkat efisiensinya semakin meningkat karena nilai koefisiennya yang bernilai positif $(0,0049738)$. Pendidikan dapat meningkatkan kemampuan seorang petani untuk mencari, memperoleh dan menginterpretasikan informasi yang bermanfaat terkaitfaktor-faktor produksi. Artinya tingginya tingkat pendidikan juga akan berdampak pada kemauan maupun kemampuan seorang petani dalam mengakses informasi terkait penggunaan faktor produksi.

Jika dilihat dari jumlah tanggungan anggota rumah tangga, semakin banyak jumlah tanggungan anggota rumah tangga maka tingkat efisiensinya semakin meningkat pula karena nilai 
koefisiennya yang bernilai positif $(0,108186)$. Hal tersebut dengan melihat jumlah anggota rumah tangga yang aktif dalam menjalankan usahatani padi tersebut.

Jika dilihat dari lama pengalaman berusahatani padi, lama pengalaman berusahatani padi tidak berpengaruh sebab hal tersebut tidak menentukan usahatani yang dilakukan lebih efisien karena petani yang memiliki pengalaman lebih sedikit bisa saja belajar dari pengalaman petani yang lain atau sharing melalui penyuluhan dalam kelompok tani.

\subsection{Penerimaan Usahahatani Padi}

Adapun nilai produksi dan pendapatan usahatani padi oleh petani di Kecamatan Barambai dapat dilihat pada Tabel 3.

\begin{tabular}{lcrr}
\multicolumn{4}{c}{ Tabel 3. Penerimaan usahatani padi oleh petani di Kecamatan Barambai } \\
\hline \multicolumn{1}{c}{ Uraian } & Satuan & Per usahatani & \multicolumn{1}{c}{ Per hektar } \\
\hline Produksi & GKG & 2.094 & 2.441 \\
Harga (satuan) & Rp / GKG & 6.500 & 7.579 \\
Penerimaan & Rp & 13.609 .917 & 15.869 .420 \\
\hline
\end{tabular}

Sumber: Pengolahan data primer (2019)

Penerimaan adalah nilai dari hasil panen yang sudah melalui tahap pasca panen dan siap digiling dikalikan dengan nilai jual per unit.

\subsection{Biaya Eksplisit Usahatani}

Adapun rata-rata total biaya eksplisit yang dikeluarkan petani Padi sawah pasang surut di Kecamatan Barambai yang menjadi sampel dapat dilihat pada Tabel 4.

Tabel 4. Rata-rata total biaya eksplisit

\begin{tabular}{lrr}
\hline \multicolumn{1}{c}{ Biaya-biaya eksplisit } & $\begin{array}{c}\text { Biaya eksplisit } \\
\text { /usahatani (Rp) }\end{array}$ & $\begin{array}{c}\text { Biaya eksplisit /hektar } \\
\text { (Rp) }\end{array}$ \\
\hline Biaya pupuk & 511.757 & 596.718 \\
Biaya pestisida & 371.229 & 432.860 \\
Biaya penyusutan peralatan dan & 505.944 & 589.939 \\
perlengkapan & 274.687 & 308.631 \\
Biaya TKLK & 545.000 & 635.480 \\
Biaya mekanisasi $\quad$ Total & 2.198 .617 & 2.563 .628 \\
\hline \multicolumn{2}{c}{ Sumber: Pengolahan data primer (2019) } &
\end{tabular}

Biaya eksplisit usahatani merupakan biaya yang secara nyata dikeluarkan oleh petani dalam pelaksanaan usahataninya, mulai dari persiapan usahatani hingga pasca panen.

\subsection{Biaya Implisit Usahatani}

Adapun rata-rata total biaya implisit yang dikeluarkan petani Padi sawah pasang surut di kecamatan Barambai yang menjadi sampel dapat dilihat pada Tabel 5.

\begin{tabular}{|c|c|c|}
\hline Biaya implisit & $\begin{array}{l}\text { Biaya implisit } \\
\text { /usahatani(Rp) }\end{array}$ & Biaya implisit /hektar(Rp) \\
\hline Biaya benih sendiri & 42.006 & 48.980 \\
\hline Biaya TKDK & 4.196 .792 & 4.893 .550 \\
\hline Total & 4.238 .798 & 4.942 .530 \\
\hline
\end{tabular}

Biaya implisit usahatani merupakan biaya yang dikeluarkan secara tidak langsung oleh petani itu sendiri selama proses usahatani tersebut dijalankan.

\subsection{Pendapatan dan Keuntungan Usahatani}

Adapun pendapatan dan keuntungan usahatani padi sawah dapat dilihat pada Tabel 6 . 
Tabel 6. Rata-rata pendapatan dan keuntungan usahatani padi

\begin{tabular}{|c|c|c|}
\hline Petani & Per usahatani (Rp) & Per hektar (Rp) \\
\hline Pendapatan & 11.411 .300 & 13.305 .792 \\
\hline Keuntungan & 7.172 .502 & 8.363 .262 \\
\hline
\end{tabular}

Pendapatan usahatani adalah penerimaan dikurangi dengan biaya total eksplisit. Keuntungan usahatani adalah pengurangan antara penerimaan usahatani dengan total biaya usahatani padi selama usahatani tersebut dijalankan (biaya eksplisit ditambah dengan biaya implisit).

\section{KESIMPULAN}

\section{Kesimpulan}

Berdasarkan hasil analisis yang telah dilakukan, maka dapat ditarik kesimpulan yaitu:

1. Rata-rata tingkat efisiensi petani padi sawah pasang surut di Kecamatan Barambai tahun 2018 sebesar 0,893 .

2. Terdapat 3 karakteristik responden yang berpengaruh terhadap efisiensi teknis di Kecamatan Barambai yaitu, usia petani sampel, lama pendidikan formal, dan jumlah tanggungan anggota rumah tangga. Sedangkan karakteristik yang tidak berpengaruh terhadap efisiensi teknis di Kecamatan Barambai adalah lama pengalaman berusahatani padi.

3. Keuntungan yang diperoleh padi sawah pasang surut di Kecamatan Barambai tahun 2018 adalah sebesar Rp 7.172.502 /usahatani atau Rp 8.363.262/ha.

Berdasarkan hasil penelitian yang saya lakukan, maka sebaiknya petani mengurangi beberapa penggunaan input (faktor produksi) yang berlebih seperti penggunaan input (faktor produksi) pupuk, benih, pestisida, TK manusia, TK mesin dan lain-lain dengan memperhatikan input slack yang ada, sehingga usahatani yang dilaksanakan berada pada kategori usahatani yang efisien dan bisa meningkatkan keuntungan usahatani.

\section{DAFTAR PUSTAKA}

BPS.2017.Provinsi Kalimantan Selatan Dalam Angka.BPS, Kalimantan Selatan

Soekartawi. 1995. Analisis Usahatani. UI Press, Jakarta

Soekartawi, A. Soeharjo, J. L. Dillon\&J. BHardaker.1986. Ilmu Usahatani dan Penelitian untuk Pengambangan Petani Kecil. UI Press, Jakarta

Dumaria, E. 2003. Analisis Efisiensi Usahatani Nenas di Desa Tambakan Kecamatan Jalancagak Kabupaten Subang Jawa Barat. Skripsi. Fakultas Pertanian, Institut Pertanian Bogor, Bogor

Sudaryanto, B. 2006. Analisis Efisiensi Kinerja Pengelolaan Tempat Pelelangan Ikan(TPI) dengan Data Envelopment Analysis (DEA). Studi di Kabupaten Pati dan Kabupaten Rembang, Jawa Tengah 